\title{
Aquatic insects, a tool for monitoring the health of riverine ecosystem, a case study of Killiyar, Thiruvananthapuram, Kerala, India
}

\section{Insectos acuáticos, una herramienta para monitorear la salud del ecosistema riverino, un estudio de caso de Killiyar, Thiruvananthapuram, Kerala, India}

Jyothylakshmi. K ${ }^{1 *}$, Kurian Mathew Abraham², S. Nandakumar ${ }^{3}$ and M.G. Sanal Kumar ${ }^{4}$ $1 \& 2$ Dept. of Aquatic Biology and Fisheries, University of Kerala, Thiruvananthapuram, Kerala, India

3\&4 Post Graduate and Research Department of Zoology, NSS College, Pandalam, Kerala, India

*Corresponding author: Jyothylakshmik@gmail.com

\section{ABSTRACT}

Aquatic insects are used as model organisms for assessing the health status of lenthic or lotic ecosystems. Biomonitoring using entomological indicators is one of the widely accepted tools to analyze the impacts of sewages in aquatic environment. The present study was aimed to assess the health status of a semi urban river system, Killiyar using entomological indicators. Season wise sampling of aquatic insects was done at four selected segments according to the rapid bioassessment protocol recommended by Environmental Protection Agency. The present study could identify 29 families of aquatic insects for screening the levels of pollution in Killiyar. Family Biotic Index (FBI) showed that there was a remarkable variation in water quality along the river. Hilsenhoff's family biotic index obtained for river origin was in the range 4.40 - 5.02 indicating excellent water quality. High value of family biotic index, least occurrence of intolerant groups and dominance of tolerant taxa in the midstream and downstream segments showed that increased contamination of water by various sources. Immediate attention is needed to cease the degradation of this precious ecosystem.

Keywords: Aquatic insects, Biomonitoring, Family Biotic Index, Killiyar, Water pollution 


\section{RESUMEN}

Los insectos acuáticos se utilizan como organismos modelo para evaluar el estado de salud de los ecosistemas lénticos o lóticos. El biomonitoreo utilizando indicadores entomológicos es una de las herramientas ampliamente aceptadas para analizar los impactos de las aguas residuales en el medio ambiente acuático. El presente estudio tuvo como objetivo evaluar el estado de salud de un sistema fluvial semiurbano, Killiyar utilizando indicadores entomológicos. El muestreo de insectos acuáticos según la estación se realizó en cuatro segmentos seleccionados de acuerdo con el protocolo de bioevaluación rápida recomendado por la Agencia de Protección Ambiental. El presente estudio podría identificar 29 familias de insectos acuáticos para detectar los niveles de contaminación en Killiyar. El Índice Biótico Familiar (FBI) mostró que había una variación notable en la calidad del agua a lo largo del río. El índice biótico familiar de Hilsenhoff obtenido para el origen del río estaba en el rango de 4.40 - 5.02, lo que indica una excelente calidad del agua. El alto valor del índice biótico familiar, la menor ocurrencia de grupos intolerantes y el dominio de taxones tolerantes en los segmentos intermedio y aguas abajo mostraron que la contaminación del agua aumentaba por varias fuentes. Se necesita atención inmediata para detener la degradación de este precioso ecosistema.

Palabras clave: Insectos acuáticos, Biomonitoreo, Índice biótico familiar, Killiyar, Contaminación del agua.

\section{INTRODUCTION}

The impacts of human induced activities on fresh water ecosystems are beyond our imagination. It results in the structural as well as functional disturbances in the ecosystem finally leads to reduction and loss of biodiversity. The use of biological organisms to assess the water quality is a traditional approach. Biomonitoring has several advantages because physico chemical data reflect the condition of ecosystem only during the time of sampling. But Biomonitoring gives an indication of the long time condition of the ecosystem due to sedentary nature of benthic organisms (Resh and Rosenberg, 1993). The use of aquatic insects as bioindicators is an effective tool to estimate the intensity of environmental impact (Wahizatul, et al., 2011). Aquatic insects are those they spend some part of their life stages in water either they living beneath the water or skimming through the surface (Resh and Carde, 2009). Aquatic insects, a very good indicator of water quality of aquatic ecosystems and they have various tolerance levels towards environmental disturbances (Arimoro and Ikomi, 2008). Some insects groups are highly sensitive to water pollution others can survive 
and proliferate in extremely disturbed or polluted environment (Hepp et al., 2013; Merritt and Cummins, 1996).

Fresh water insects play an important role in maintaining the ecology of riverine ecosystem. They are necessary for riparian and flood plain food web, processing of organic matter, transport of energy and their biological interaction have a significant role in shaping the community structure. So their diversity, distribution and abundance are regularly monitored as an indication of the health of running water body (Boulton and Lake, 2008). Their sedentary nature helps to use them as indicators of changes in the aquatic environment. Several species are highly tolerant to pollution and some of the orders are pollution sensitive (Barbour et al., 1999). Especially the insects under order Ephemeroptera, Plecoptera and Trichoptera require good water quality for their existence (Cushing and Allan, 2001).

Human induced disturbances of aquatic habitat include pollution from point and non point source, water withdrawal and diversion for various purposes, modification of river channel can change the diversity and community structure of insects and aquatic ecosystems suffered greatly due to human induced alterations (Anne et al., 2010).

Killiyar is the main rivulet of Karamana River, originated from the hill tops, ottakompukunnu and karimchathimala in Theerthankara in Nedumangadu taluk of Thiruvananthapuram district. It flows north- south direction for about $35 \mathrm{~km}$ through Kalliodu, Panavoor, Anad, Karakulam, Kodappanakunnu and Vattiyoorkavu panchayath and it joins with the Karamana River at Pallathukadavu near Thiruvallam. Banks of the river are densely populated and they depends the water body for agricultural and domestic purposes. The river apparently reveals that it facing severe problems of pollution especially by domestic or city sewage, market waste and hospital waste. The present study is an attempt to fill the gap in the knowledge of Biomonitoring of Killiyar using entomological indicators.

\section{MATERIALS AND METHODS}

Study area: Killiyar is a major tributary of Karamana river lies along the south eastern part of Thiruvananthapuram district, is located between latitudes $8^{\circ} 40^{\prime} 30^{\prime \prime} \mathrm{N}, 8^{\circ} 27^{\prime} 0^{\prime \prime} \mathrm{N}$ and longitudes $76^{\circ} 57^{\prime} \mathrm{E}, 77^{\circ} 2^{\prime} 0 " \mathrm{E}$. Four segments along the river were demarcated as study sites for the present investigation. They were Theerthankara (River origin) lies in $\left(8^{\circ} 38^{\prime} 30.69^{\prime \prime} \mathrm{N}\right.$

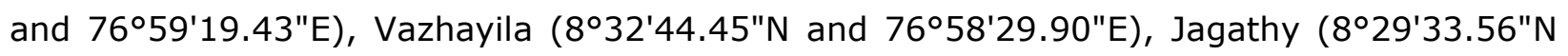
and 7657'55.63"E), and Pallathukadavu (River mouth) lies in (8²7'19.55"N and 7657'31.94"E) Fig.1. 


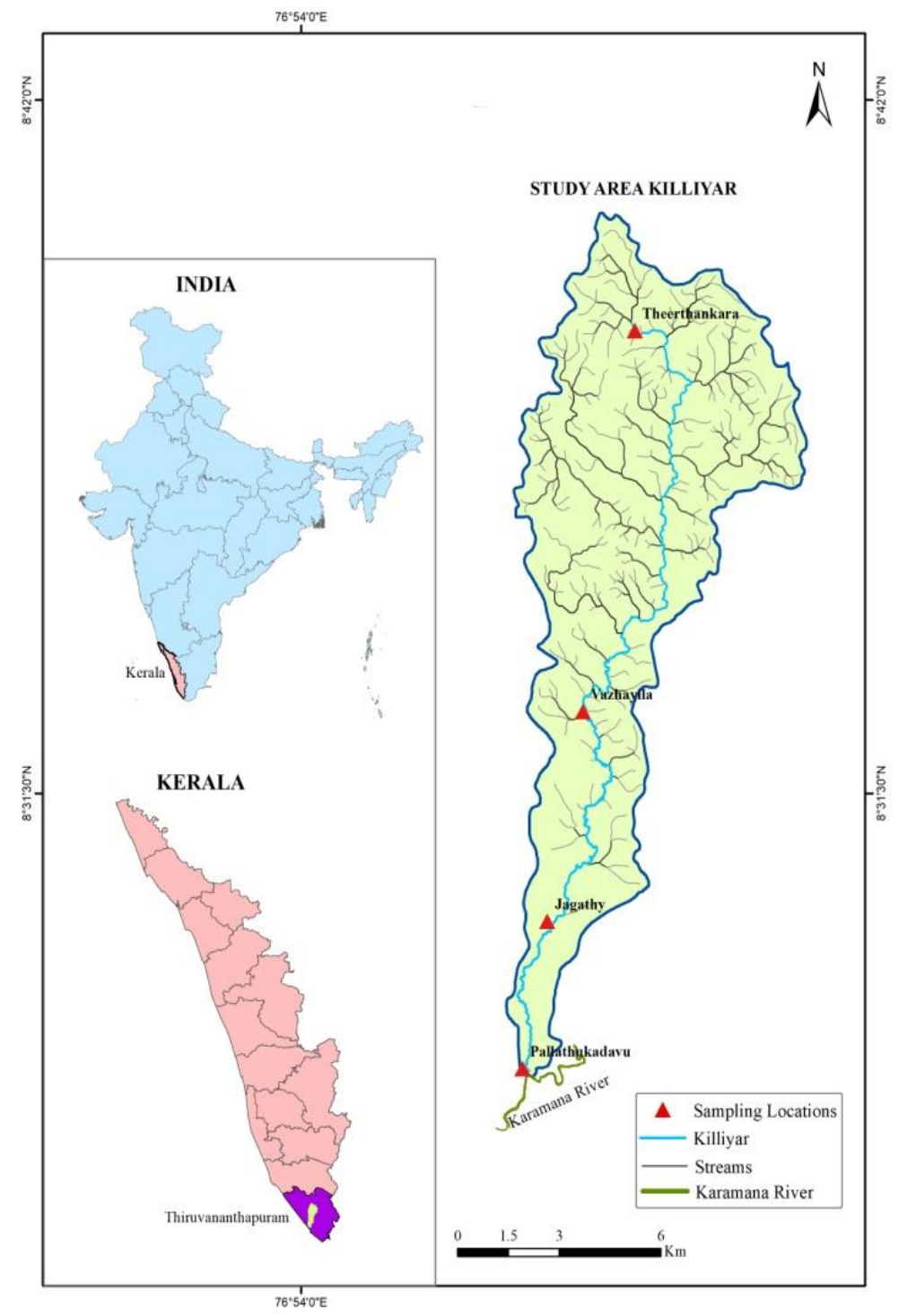

Fig.1. Location map of Killiyar with sampling sites

Aquatic insect sampling: Season wise sampling of aquatic insects was done at four selected segments in Premonsoon and Monsoon. The study period was from February 2019 to July 2019. Aquatic insects were sampled following the methodology of Rapid Bioassessment protocol (Barbour et al., 1999). Each segment was categorized into a reference site and test site except river origin where pollution was assumed at negligible level. A test site was taken as 500 meter reach of the segment where pollution was assumed to be on action where as reference site was selected 500 meter reach upstream from the source of pollution. Sampling starts at the downstream end of the reach and proceeded upstream. Bank oriented sampling was chiefly done except in shallow areas. Insects were sampled using multi habitat composite sampling method (Barbour et al., 1999). The duration of sampling was set as 2 hours which was consistently maintained for each site. The sampling gears used were the kick screen net 
with mesh size $600 \mu$, D- frame net mesh size $500 \mu$ and a Peterson grab was used for sediment sampling. It was used where water depth exceeded 1 meter.

Identification of aquatic insects: Samples were examined under stereo zoom microscope (OLYMPUS- SZX16). Collected adult insects and their larvae were identified up to family level by using the suitable key (Morse et al., 1994; Yule and Yong, 2004). The photographs of insects were taken using Olympus TG- 5 digital camera. Selected taxa kept in separate vials containing $70 \%$ ethanol and properly labelled. Identify the number of organisms in each collection also.

Benthic metrics and data analysis: The benthic metrics calculated were structure metrics; it included total taxa richness, EPT (Ephemeroptera, Plecoptera, and Trichoptera) abundance and EPT taxa richness. Composition metrics means the Percentage composition of insects under Ephemeroptera alone and the composition of EPT. Tolerance metrics; Tolerance and intolerance measures were calculated by sorting families on the basis of tolerance values of insects. Families having tolerance value 5.0 and above were categorized as tolerant organisms and intolerant taxa were taken as the sum of EPT.

Feeding metrics; Percentage composition of filterers, grazers and scrapers were calculated as feeding metrics.Habitat metrics; Number of families having clinging habit and percentage composition of clingers were calculated as habit metrics and Hilsenhoff's Family Biotic Index, (Barbour et al., 1999). Pollution tolerance of insects and other measures used in this study has been adopted from the modified values for Asian region (Morse et al., 1994). All results were analyzed for significant level of pollution using Hilsenhoff's Family Biotic Index (Hilsenhoff, 1988).

\section{RESULTS AND DISCUSSION}

During the present study, a total of 29 families of insects under 7 orders could be identified from selected segments of Killi River for rapid bioassessment purpose (Table1). A total of 19 taxa were obtained from river origin during Premonsoon season. Among the samples collected 6 taxa represent the intolerant groups Ephemeroptera, Plecoptera and Trichoptera with a percentage composition of $42.6 \%$. Total number of organisms was 122 among which tolerant organisms constituted $49.1 \%$ and dominant taxa constituted $11.4 \%$. Family Caenidae (Ephemeroptera) was the most dominant group during this season. Filterers represented by Trichoptera and Diptera with a percentage composition of $17.2 \%$. Grazers and Scrappers were $27.8 \%$. Clingers contributed $41.8 \%$ with a number of 7 taxa out of total 19 taxa. Family biotic index was 5.02 for river origin during Premonsoon season (Table 2). 
Insect samples collected from river origin during monsoon season showed 22 families with a high number of intolerant taxa. A total of 7 taxa represented the intolerant organisms under EPT. The percentage composition of EPT was found to be $46.7 \%$ and observed that the number of insects from Order Ephemeroptera, Plecoptera and Trichoptera were 39, 12 and 20 respectively out of 152 organisms. The number of tolerant organisms was found to be 75 and showed a percentage composition of $49.3 \%$ dominant taxa was represented by Fam. Hydropsychidae (Trichoptera) with a percentage composition of $10.5 \%$. Filterers were represented by Hydropsychidae and Stenopsychidae under Trichoptera and Chironomidae and Simulidae under Diptera and contributed $19 \%$ of the total organisms. Grazers and Scrappers were $28.2 \%$ out of the total organisms sampled during monsoon season from river origin. Clingers were represented by 8 taxa with a percentage composition of $48.6 \%$. Hilsenhoff's family biotic index obtained for river origin during monsoon season was 4.40 (Table 3).

Killiyar at its origin was found to be pure in nature during the period of study due to lack of any anthropogenic activities. The major aquatic insect taxa at this segment were Ephemeroptera, Plecoptera and Trichoptera in contrast to other insect groups in percentage. This is mainly due to clean and well oxygenated conditions of water and they are highly sensitive to environmental perturbations. EPT richness is frequently considered as indicator of good water quality (Rosenberg, 1993). Hilsenhoff's family biotic index obtained for river origin was in the range 4.40 - 5.02. Family biotic index value below 5.24 has been considered as excellent water quality indicator (Hilsenhoff, 1988). EPT taxa richness and family biotic index strongly supported the purity of water at origin of Killiyar during present study.

Insect samples collected from Vazhayila segment of the river during Premonsoon season showed 13 taxa from the reference site and 9 taxa from test site. Number of EPT showed 3 taxa from the reference site and only 2 taxa could be obtained from test site. Percentage composition of EPT at reference site was $45.7 \%$ represented by Fam. Caenidae (Ephemeroptera) and Hydropsychidae and Polycentropodidae (Trichoptera). Plecopterans were completely absent in this site during Premonsoon season. At the same time only $11.6 \%$ of EPT could be found at test site represented by Caenidae under Ephemeroptera and Polycentropodidae (Trichoptera). Similar trends in the absence of Plecopterans also were found at the test site. Tolerant organisms were found to be $82.8 \%$ at reference site and a considerable increase in tolerant groups was noticed in the test site with a percentage composition of $84.4 \%$. The percentage of dominant taxa was found to be $22.8 \%$ at reference site and $34.9 \%$ at test site. But the dominant aquatic insect group varied Caenidae at reference site and Coenagrionidae at test site. Filterers were represented by Trichoptera and Diptera which consisted about $25.7 \%$ at reference site and $28.1 \%$ at test site. Grazers and 
Scrappers were $24.7 \%$ at reference site and a considerable decrease in the number of Grazers and Scrappers were noticed on test site with a percentage composition of $5.8 \%$. Number of Clinger taxa was 4 at reference site and 2 at test site with percentage compositions of $30.4 \%$ and $17.4 \%$ respectively. Family biotic index values were almost similar at both sites 6.99 at test site and 6.32 at reference site respectively (Table 2). Monsoon collection of insects showed a richness of 16 families at reference site and 11 from test site. Percentage composition of EPT taxa was 39.2\% at reference site represented by 4 families Baetidae, Caenidae, Potamanthidae under Ephemeroptera and Hydropsychidae under Trichoptera and Plecoptera was completely absent. But it got declined at test site which is about $30.6 \%$. Tolerant organisms at reference site with a percentage composition of $52.6 \%$ out of 112 organisms collected. Where as a sharp increase in tolerant groups were noticed on test site with a percentage composition of $79.5 \%$. The percentage of dominant taxa was found to be $21.4 \%$ at reference site out of 112 organisms collected which was represented by Fam. Baetidae and $17.3 \%$ of dominant organisms could be seen at test site. Increased number of filterers could be seen at the test site with $28.5 \%$ while only $16.9 \%$ were present at reference site. But Grazers and Scrappers were found to be only $22.4 \%$ at test site and a slight increase of $39.2 \%$ was noticed on reference site during monsoon season. Clingers represented about $39.2 \%$ at reference site and $25.5 \%$ at test site. A family biotic index value of 6.64 at test site was higher than 5.33 which were obtained for reference site during monsoon season (Table 3).

Plecopterans were completely absent on this segment. Order Plecoptera is highly sensitive to environmental degradation (Fore et al., 1996). Baetidae was the dominant group at reference site of vazhayila segment during monsoon season. Even at test site a notable number of baetids was observed during monsoon. This is mainly due to their tolerance potential and they can tolerate some levels of environmental contamination caused by domestic sewage (Goulart and Callisto, 2003). Chironomidae and Coenagrionidae were dominants at the test site of Vazhayila segment during Premonsoon season. Chironomidae possess hemoglobin to satisfy their physiological demands in hypoxic conditions. It helps in transporting and storing oxygen in the larvae that burrow in polluted mud (Osmulski and Leyko, 1986). Presence of duplex gills is peculiar for Coenagrionidae that makes them to adapt to poor oxygen concentration (Rahn and Paganelli, 1968). Striking difference in the family biotic index could be seen in monsoon season which might be due to inflow of more fresh water by rainfall that dilutes the contaminants. A family biotic index value of 5.33 was obtained for reference site during monsoon indicate good water quality and a biotic index 
value of 6.64 was obtained for test site are classified as good - fair water quality for coastal plain rivers (Hilsenhoff, 1988).

In Jagathy it could be observed that 8 families of insects were collected from the reference site and 6 families of insects were obtained from test site during Premonsoon. The EPT taxa were completely absent on reference as well as in the test site during collection. The percentage of tolerant organisms at reference site was found to be $54.4 \%$ and a sharp increase was noticed on test site with a percentage composition of $73 \%$. The dominant taxa were Coenagrionidae at both sites with percentage compositions of $27.7 \%$ and $42 \%$ respectively. Chironomidae under Diptera was the only filtering group collected during Premonsoon season with percentage compositions of $7.9 \%$ at reference site and $20 \%$ at test site. Grazers and Scrappers were found to be absent on both sites. Clingers contributed single taxa at both sites and were represented by Naucoridae under Hemiptera. Family biotic index was high at test site with a value of 7.03 in contrast to family biotic index of 6.07 at reference site (Table 2).

Jagathy segment revealed complete absence of intolerant organisms such as Ephemeroptera, Plecoptera and Trichoptera during monsoon season. Taxa richness was found to be 11 taxa at reference site and only 7 taxa at test site. But at the same time tolerant organisms contributed $53.3 \%$ at reference site and a sharp increase in the number of tolerant organisms was noticed on test site with a percentage composition of $81.3 \%$. The dominant taxa were Belostomatidae at reference site and Coenagrionidae at test site with percentage compositions of $16.5 \%$ and $26.7 \%$ respectively. Filterers were Culicidae and Chironomidae under order Diptera that contributed $26.7 \%$ at test site and $12.6 \%$ at reference site. The insects having Grazing and Scrapping habits were completely absent on both sites during monsoon collection. Clingers represented only single Family at both sites with percentage compositions of $12.6 \%$ at reference site and $12.7 \%$ at test site. Family biotic index was showed a striking difference with values of 5.34 at reference site and 6.72 at test site (Table 3).

Dumping of waste materials into the river can cause severe impact on the survival of aquatic organisms (Nummelin et al., 2007). EPT taxa are highly sensitive to changes in water and substrate quality. The number of EPT taxa decreases with increasing anthropogenic impacts (Lenat and Barbour, 1994). Coenagrionidae was the dominant group observed at this segment during the study. Variation in composition and distribution of benthic entamofauna was reported between different seasons and the insect order Odonata was dominant during pre-monsoon season over the other taxa (Dinesh et al., 2017). This might be due to their potential to tolerate wide environmental fluctuations. FBI value of 7.03 was obtained at test 
site during Premonsoon season and 6.72 during monsoon. Family biotic index $6.68-7.70$ is considered as fair water quality (Morse et al., 1994).

Premonsoon collection of insects from Pallathukadavu segment showed only a slight variation in taxa richness 8 taxa at reference site and 6 taxa at test site with a percentage composition of zero EPT. Tolerance measures showed $78.8 \%$ at reference site and a sharp increase was noticed on test site with a percentage composition of $90 \%$. Dominant taxon was Coenagrionidae (Odonata), it was found to be $35.2 \%$ at reference site and $40 \%$ at test site. $7 \%$ of organisms were filterers at reference site while $32.9 \%$ were filters at test site during Premonsoon season. Insects having Grazing and Scrapping habits were completely absent on both sites during Premonsoon collection. $11.7 \%$ of the total insects were preferred clinging habitat at reference site in contrast with $5.8 \%$ at test site. Family biotic index value was too high at test site with a value of 7.98 in comparison to 6.33 at reference site (Table 2). Sampled insects from Pallathukadavu segment during monsoon showed a taxa richness of 9 families at reference site and 7 families at test site. EPT taxa were completely absent on both sites during the collection. Percentage composition of tolerant organisms was $68.8 \%$ at test site and was slightly high when compared to reference site which had $63.4 \%$ during monsoon. Coenagrionidae under Odonata was dominated at reference site with a percentage composition of $25 \%$ and where as in the test site it was about $31.1 \%$. Filterers represented by Culicidae and Chironomidae under Diptera with $19.2 \%$ at reference site with a value of $26.8 \%$ at test site. Grazers and Scrappers were absent on both sites. Clingers were notably absent at test site while $7.6 \%$ of clingers at reference site consisted Naucoridae under Hemiptera. Family biotic index value was high at test site with a value of 7.22 and a decrease in FBI was noticed at reference site with a value of 6.27 (Table 3).

Pallathukadavu segment was found to be the most polluted segment of the river region where merge with the Karamana river. Greater number of tolerant insects and reduced number of sensitive insect were found at this segment during the period of study. This segment also characterized by the total absence of EPT taxa due to severe impairment. A family biotic index value of 7.98 was observed at test site during Premonsoon season indicates poor quality of water. Monsoon rainfall results in the alteration of biotic index value to 7.22 which indicate fair quality of water (Morse et al., 1994). The survival of aquatic insect population is severely affected due to anthropogenic input.

Several aquatic insects are highly sensitive to pollution therefore they are used as ecological indicators. They play a major role in maintaining the health of the ecosystem by balancing the food chain, cleaning and decomposition of organic materials. Decline to these insect communities will ultimately results in the disruption of ecosystem services. 
Table 1. Taxonomic distribution and tolerance value of Aquatic insects

\begin{tabular}{|c|c|c|c|}
\hline \multirow{2}{*}{ SI.No } & \multicolumn{2}{|c|}{ TAXA } & \multirow{2}{*}{ TOLERANCE VALUE $(T V)$} \\
\hline & Order & Family & \\
\hline 1 & Ephemeroptera & Caenidae & 7.6 \\
\hline 2 & & Baetidae & 4 \\
\hline 3 & & Heptageniidae & 5 \\
\hline 4 & & Potamanthidae & 5 \\
\hline 5 & Plecoptera & Perlidae & 1 \\
\hline 6 & Trichoptera & Hydropsychidae & 6 \\
\hline 7 & & Stenopsychidae & 0 \\
\hline 8 & & Polycentropodidae & 6 \\
\hline 9 & Odonata & Gomphidae & 1 \\
\hline 10 & & Macromiidae & 3 \\
\hline 11 & & Corduliidae & 4 \\
\hline 12 & & Calopterygidae & 5 \\
\hline 13 & & Coenagrionidae & 9 \\
\hline 14 & & Chlorocyphidae & 0 \\
\hline 15 & & Euphaeidae & 0 \\
\hline 16 & Hemiptera & Gerridae & 5 \\
\hline 17 & & Veliidae & 0 \\
\hline 18 & & Belostomatidae & 0 \\
\hline 19 & & Naucoridae & 5 \\
\hline 20 & & Notonectidae & 0 \\
\hline 21 & & Hebridae & 0 \\
\hline 22 & Diptera & Chironomidae & 6 \\
\hline 23 & & Tipulidae & 3 \\
\hline 24 & & Simulidae & 6 \\
\hline 25 & & Tabanidae & 6 \\
\hline 26 & & Culicidae & 9.5 \\
\hline 27 & Coleoptera & Hydrophilidae & 5 \\
\hline 28 & & Psephenidae & 4 \\
\hline 29 & & Dytiscidae & 5 \\
\hline
\end{tabular}


Table 2. Tabulated matrices of samples collected from four segments of Killiyar during Premonsoon season

\begin{tabular}{|c|c|c|c|c|c|c|c|}
\hline \multirow[t]{2}{*}{ Benthic Metrics } & \multirow[t]{2}{*}{$\begin{array}{l}\text { River } \\
\text { Origin }\end{array}$} & \multicolumn{2}{|c|}{ Vazhayila Segment } & \multicolumn{2}{|c|}{ Jagathy Segment } & \multicolumn{2}{|c|}{$\begin{array}{l}\text { Pallathukadavu } \\
\text { Segment }\end{array}$} \\
\hline & & $\begin{array}{l}\text { Reference } \\
\text { site }\end{array}$ & $\begin{array}{l}\text { Test } \\
\text { site }\end{array}$ & $\begin{array}{l}\text { Reference } \\
\text { site }\end{array}$ & $\begin{array}{l}\text { Test } \\
\text { site }\end{array}$ & $\begin{array}{l}\text { Reference } \\
\text { site }\end{array}$ & $\begin{array}{l}\text { Test } \\
\text { site }\end{array}$ \\
\hline Total taxa & 19 & 13 & 9 & 8 & 6 & 8 & 6 \\
\hline Number of EPT taxa & 6 & 3 & 2 & 0 & 0 & 0 & 0 \\
\hline Number of E.taxa & 3 & 1 & 1 & 0 & 0 & 0 & 0 \\
\hline Number of P.taxa & 1 & 0 & 0 & 0 & 0 & 0 & 0 \\
\hline Number of T.taxa & 2 & 2 & 1 & 0 & 0 & 0 & 0 \\
\hline Percentage of EPT & 42.6 & 45.7 & 11.6 & 0 & 0 & 0 & 0 \\
\hline $\begin{array}{l}\text { Percentage of } \\
\text { Ephemeroptera }\end{array}$ & 22.9 & 22.8 & 5.8 & 0 & 0 & 0 & 0 \\
\hline $\begin{array}{c}\text { Number of intolerant } \\
\text { taxa }\end{array}$ & 6 & 3 & 2 & 0 & 0 & 0 & 0 \\
\hline $\begin{array}{c}\text { Percentage of tolerant } \\
\text { organisms }\end{array}$ & 49.1 & 82.8 & 84.4 & 54.4 & 73 & 78.8 & 90 \\
\hline $\begin{array}{l}\text { Percentage of } \\
\text { dominant taxa }\end{array}$ & 11.4 & 22.8 & 34.9 & 27.7 & 42 & 35.2 & 40 \\
\hline Percentage of filterers & 17.2 & 25.7 & 28.1 & 7.9 & 20 & 7 & 32.9 \\
\hline $\begin{array}{c}\text { Percentage of Grazers } \\
\text { \& Scrappers }\end{array}$ & 27.8 & 24.7 & 5.8 & 0 & 0 & 0 & 0 \\
\hline Number of Clinger taxa & 7 & 4 & 2 & 1 & 1 & 1 & 1 \\
\hline Percentage of clingers & 41.8 & 30.4 & 17.4 & 13.8 & 8 & 11.7 & 5.8 \\
\hline Family Biotic Index & 5.02 & 6.32 & 6.99 & 6.07 & 7.03 & 6.33 & 7.98 \\
\hline
\end{tabular}


Table 3. Tabulated matrices of samples collected from four segments of Killiyar during monsoon season

\begin{tabular}{|c|c|c|c|c|c|c|c|}
\hline \multirow[t]{2}{*}{ Benthic Metrics } & \multirow[t]{2}{*}{$\begin{array}{l}\text { River } \\
\text { Origin }\end{array}$} & \multicolumn{2}{|c|}{$\begin{array}{l}\text { Vazhayila } \\
\text { Segment }\end{array}$} & \multicolumn{2}{|c|}{ Jagathy Segment } & \multicolumn{2}{|c|}{$\begin{array}{l}\text { Pallathukadavu } \\
\text { Segment }\end{array}$} \\
\hline & & $\begin{array}{l}\text { Reference } \\
\text { site }\end{array}$ & $\begin{array}{l}\text { Test } \\
\text { site }\end{array}$ & $\begin{array}{l}\text { Reference } \\
\text { site }\end{array}$ & $\begin{array}{l}\text { Test } \\
\text { site }\end{array}$ & $\begin{array}{l}\text { Reference } \\
\text { site }\end{array}$ & $\begin{array}{l}\text { Test } \\
\text { site }\end{array}$ \\
\hline Total taxa & 22 & 16 & 11 & 11 & 7 & 9 & 7 \\
\hline Number of EPT taxa & 7 & 4 & 3 & 0 & 0 & 0 & 0 \\
\hline Number of E.taxa & 4 & 3 & 2 & 0 & 0 & 0 & 0 \\
\hline Number of P.taxa & 1 & 0 & 0 & 0 & 0 & 0 & 0 \\
\hline Number of T.taxa & 2 & 1 & 1 & 0 & 0 & 0 & 0 \\
\hline Percentage of EPT & 46.7 & 50 & 30.6 & 0 & 0 & 0 & 0 \\
\hline $\begin{array}{l}\text { Percentage of } \\
\text { Ephemeroptera }\end{array}$ & 25.6 & 39.2 & 22.4 & 0 & 0 & 0 & 0 \\
\hline $\begin{array}{c}\text { Number of intolerant } \\
\text { taxa }\end{array}$ & 7 & 4 & 3 & 0 & 0 & 0 & 0 \\
\hline $\begin{array}{c}\text { Percentage of tolerant } \\
\text { organisms }\end{array}$ & 49.3 & 52.6 & 79.5 & 53.3 & 81.3 & 63.4 & 68.8 \\
\hline $\begin{array}{l}\text { Percentage of dominant } \\
\text { taxa }\end{array}$ & 10.5 & 21.4 & 17.3 & 16.5 & 26.7 & 25 & 31.1 \\
\hline Percentage of filterers & 19 & 16.9 & 28.5 & 12.6 & 26.7 & 19.2 & 26.8 \\
\hline $\begin{array}{c}\text { Percentage of Grazers } \\
\text { \& Scrappers }\end{array}$ & 28.2 & 39.2 & 22.4 & 0 & 0 & 0 & 0 \\
\hline Number of Clinger taxa & 8 & 4 & 3 & 1 & 1 & 1 & 0 \\
\hline Percentage of clingers & 48.6 & 39.2 & 25.5 & 12.6 & 12.7 & 7.6 & 0 \\
\hline Family Biotic Index & 4.40 & 5.33 & 6.64 & 5.34 & 6.72 & 6.27 & 7.22 \\
\hline
\end{tabular}


Sustainability, Agri, Food and Environmental Research, (ISSN: 0719-3726), 9(4), 2021: 581-598 http://dx.doi.org/10.7770/safer-VONO-art2287

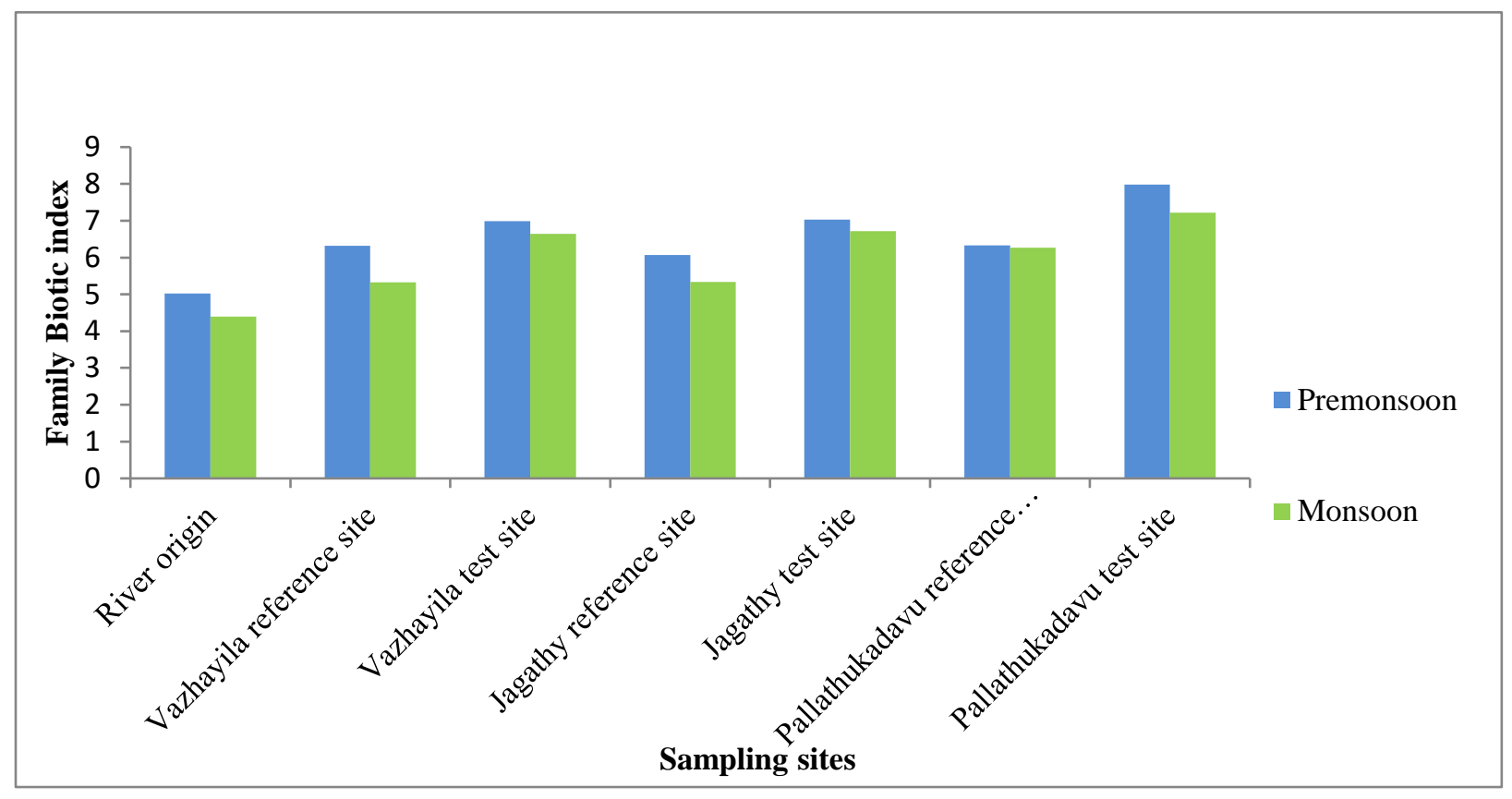

Fig.2. Variation in Family Biotic index 


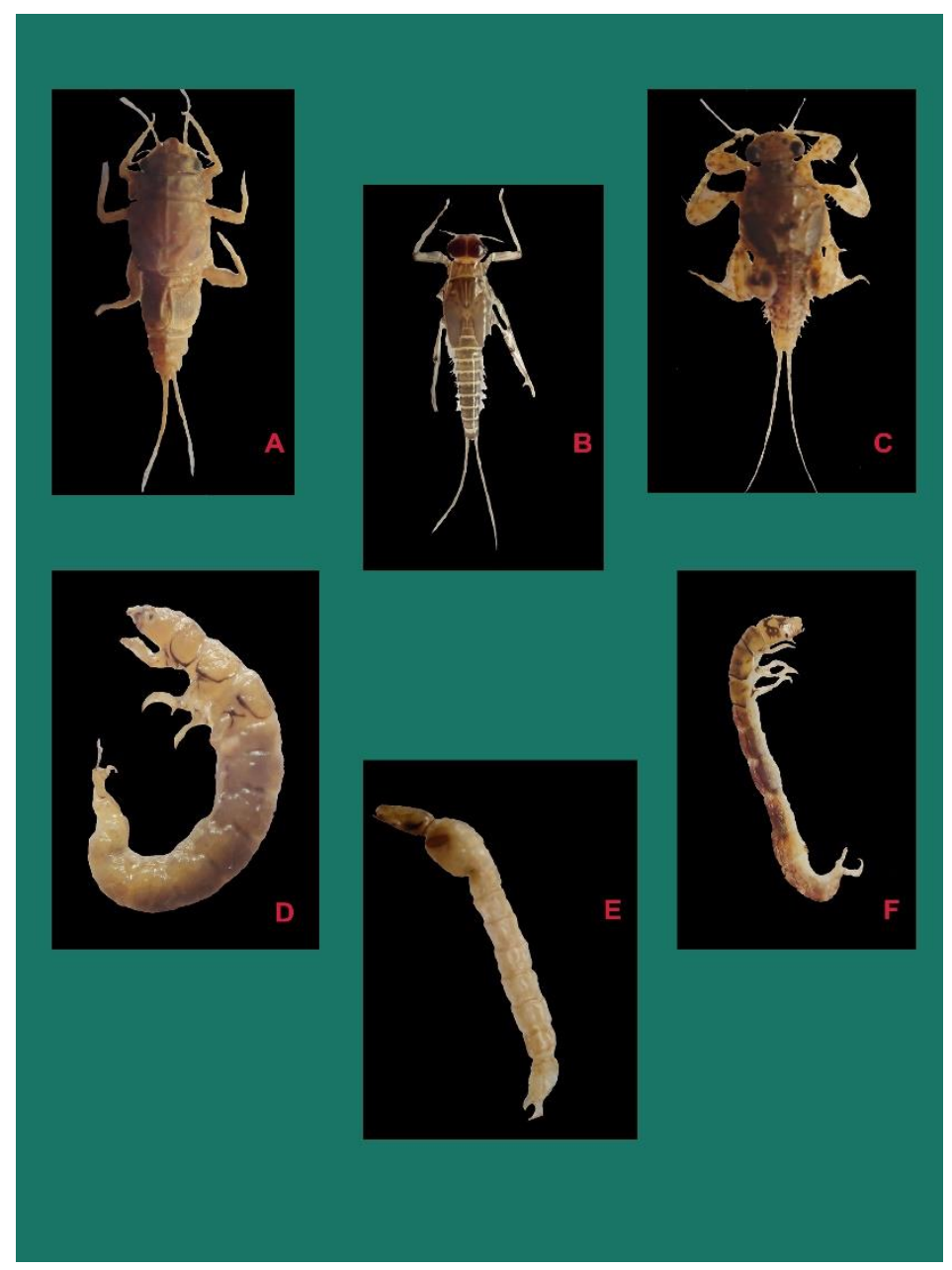

Fig.3 Order Ephemeroptera (A- C); A- Family Caenidae, B- Family Baetidae, C- Family Potamanthidae ; Order Trichoptera (D- F); D- Family Hydropsychidae, E- Family Stenopsychidae, F- Family Polycentropodidae. 


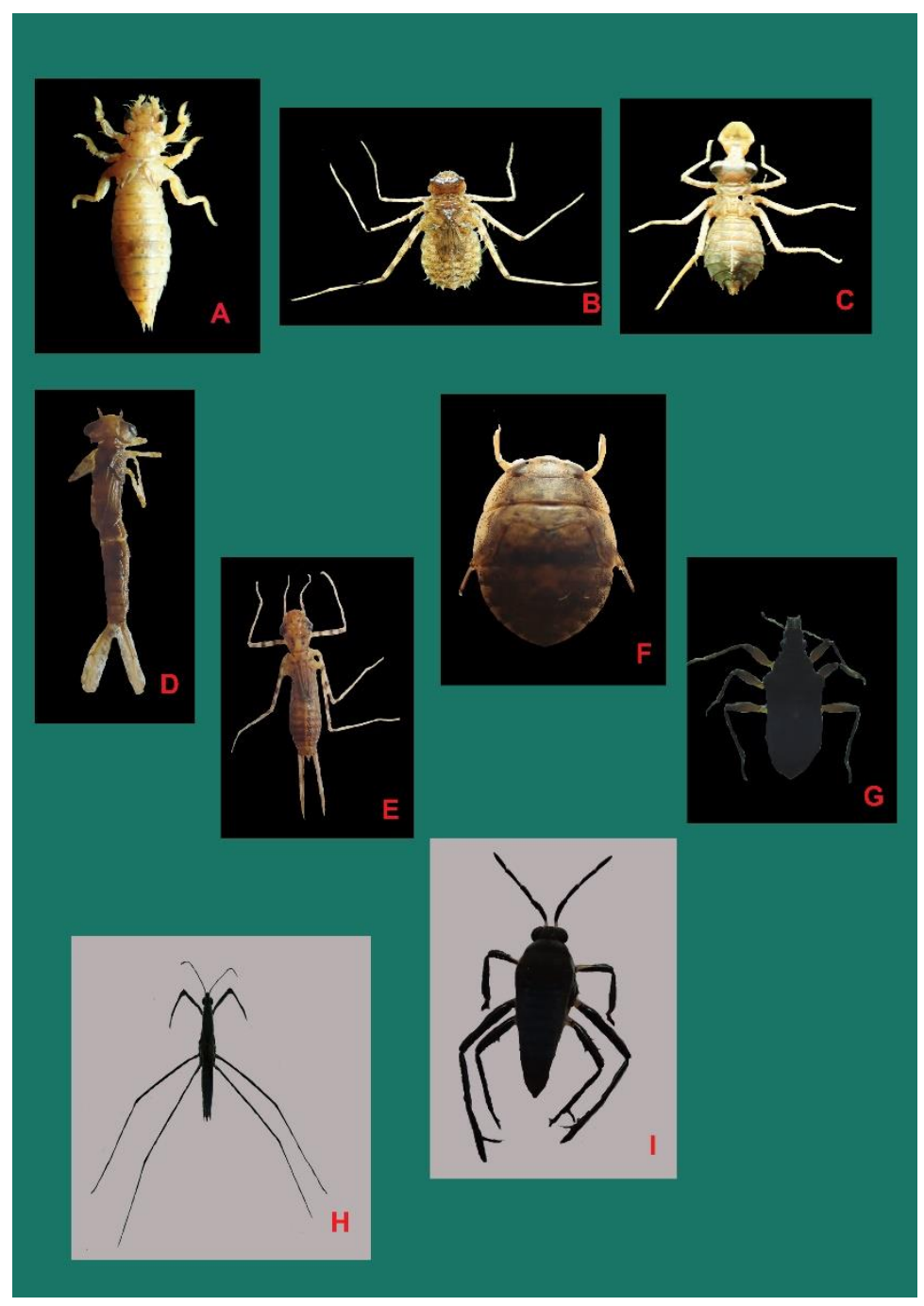

Fig.4. Order Odonata (A-E); A- Family Gomphidae, B- Family Macromiidae, C- Family Corduliidae, D- Family Coenagrionidae, E- Family Chlorocyphidae ; Order Hemiptera (F- I); F- Family Naucoridae, G- Family Hebridae, H- Family Gerridae, I- Family Veliidae. 


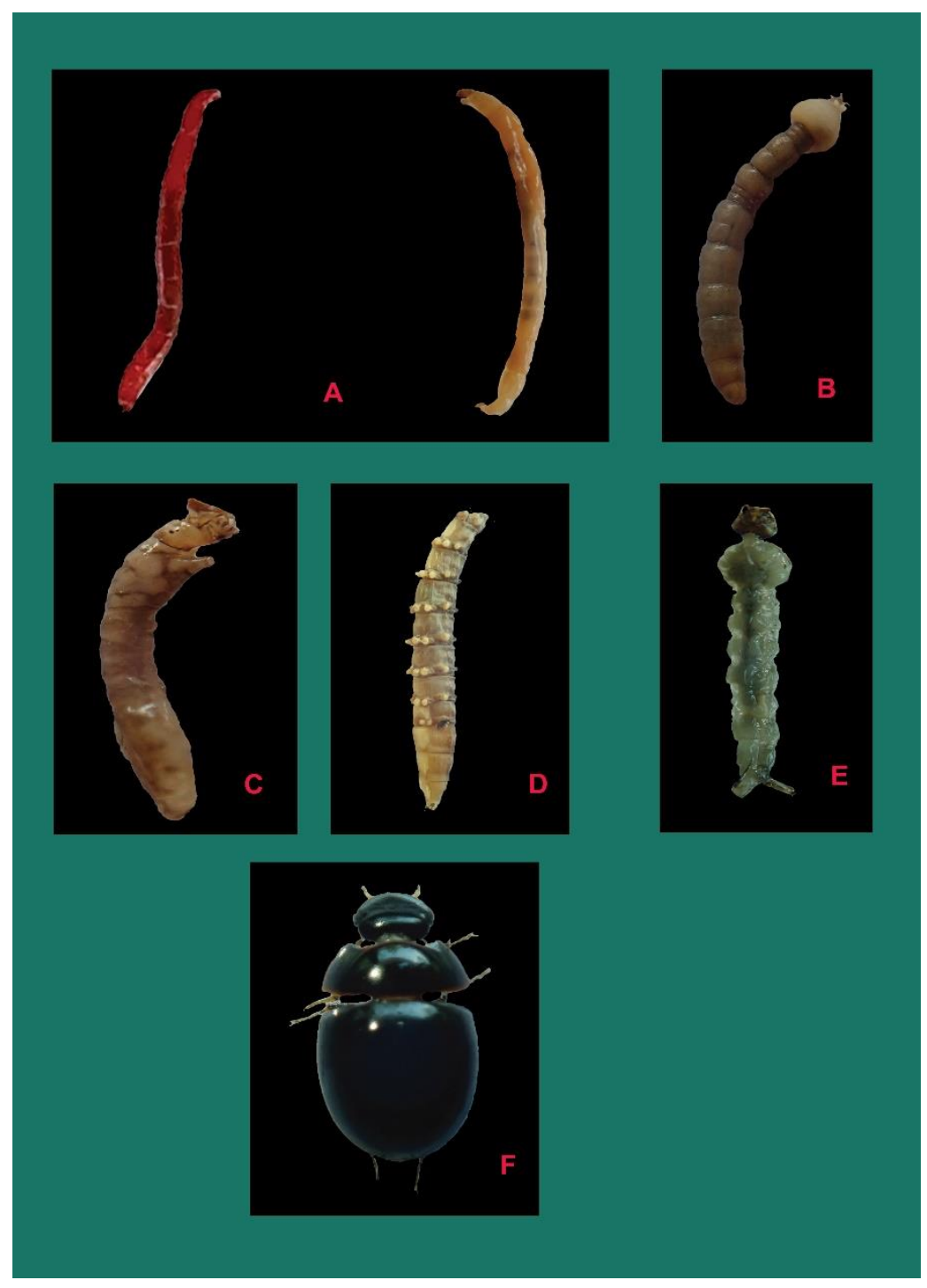

Fig.5. Order Diptera (A- E); A- Family Chironomidae, B- Family Tipulidae, C- Family Simulidae, D- Family Tabanidae, E- Family Culicidae; Order Coleoptera (F) F- Family Hydrophilidae.

As conclusion, Indicator organisms can be used to assess the intensity of pollutants and its potential effects on other living organisms in aquatic environment. So Biomonitoring using fresh water insects can be used as an effective tool to assess the current health status of freshwater ecosystems. Killiyar is a major source of freshwater to human population, especially the people inhabiting on the banks of this river. Now it is threatened by multiple stresses including anthropogenic activities. Mainly the wastes generated in cities are carried in to this water body by runoff from rain water. Biomonitoring has definitely shown an increased perturbation at three segments other than river origin. So the Killiyar has to be 
given an immediate attention in order to cease its ecosystem degradation and further depletion of aquatic biodiversity. Moreover to maintain the hydrological quality to ensure pollution free water to the population that relies upon this river.

\section{REFERENCES}

Anne E. H., Gary A. L., Dominic T. C. and Robert M. N. (2010). Aquatic Insect Ecology. In: Ecology and Classification of North American Freshwater Invertebrates,3rd Ed. Edited by J. H. Thorp and A. P. Covich. (Academic Press), California, USA: 659-694.

Arimoro, F. O. and Ikomi, R. B. (2008). Response of macroinvertebrate communities to abattoir wastes and other anthropogenic activities in a municipal stream in the Niger Delta, Nigeria. The Environmentalist, 28(2), 85-98.

Barbour, M. T., Gerritsen, J., Snyder, B. D. and Stribling, J. B. (1999). Rapid bioassessment protocols for use in streams and wadeablerivers.USEPA, Washington, (Vol. 339).

Boulton, A. J. and Lake, P. S. (2008). Effects of drought on stream insects and its ecological consequences. Aquatic insects: Challenges to populations, 2008, 81-102.

Cushing, C. E. and Allan, J. D. (2001). Streams: their ecology and life. Gulf Professional Publishing.

Dinesh, V., Joseph, L., and Josekumar, V. S. (2017). Dependence of upstream entamofauna to water quality in a semi-urbanized river (killiyar), South Kerala, India. Journal of Aquatic Biology \& Fisheries| Vol, 5, 96-106.

Fore, L. S., Karr, J. R. and Wisseman, R. W. (1996). Assessing invertebrate responses to human activities: evaluating alternative approaches. Journal of the North American Benthological Society, 15(2), 212-231.

Goulart, MD, and Callisto, M. (2003). Water quality bioindicators as a tool in environmental impact studies. FAPAM Review, 2(1), 156-164.

Hepp, L. U., Restello, R. M., Milesi, S. V., Biasi, C. and Molozzi, J. (2013). Distribution of aquatic insects in urban headwater streams. Acta LimnologicaBrasiliensia, 25(1), 1-09.

Hilsenhoff, W. L. (1988). Rapid field assessment of organic pollution with a family-level biotic index. Journal of the North American Benthological Society, 7(1), 65-68.

Lenat, D. R. and Barbour, M. T. (1994). Using benthic macroinvertebrate community structure for rapid, cost-effective, water quality monitoring: rapid bioassessment. Biological monitoring of aquatic systems. Lewis Publishers, Boca Raton, Florida, 187-215.

Merritt, R. W., Cummins, K. W. \& Berg, M. B. (2008). An Introduction to the Aquatic Insects of North America. $4^{\text {th }}($ edn $): 1158$. 
Morse, J. C., Yang, L. andTian, L. (Eds.). (1994). Aquatic insects of China useful for monitoring water quality. Hohai University Press, (No. 13).

Nummelin, M., Lodenius, M., Tulisalo, E., Hirvonen, H. and Alanko, T. (2007). Predatory insects as bioindicators of heavy metal pollution. Environmental Pollution, 145(1), 339347.

Osmulski, P. and Leyko, W. (1986). Structure, function and physiological role of Chironomus haemoglobin. Comparative Biochemistry and Physiology Part B: Comparative Biochemistry, 85(4), 701-722.

Rahn, H. and Paganelli, C. V. (1968). Gas exchange in gas gills of diving insects. Respiration physiology, 5(1), 145-164.

Resh, V. H and Carde, R. T. (Eds.). (2009). Encyclopedia of insects. Academic press.

Resh, V. H. and Rosenberg, D. M. (1993). Freshwater biomonitoring and benthic macroinvertebrates (No. 504.4 FRE).

Rosenberg, D. M. (1993). Introduction to freshwater biomonitoring and benthic macroinvertebrates. Freshwater biomonitoring and benthic macroinvertebrates, 1-9.

Wahizatul, A. A., Amirrudin, A. and Raja Noor Balqhis, R. S. (2006). Diversity of aquatic insects in relation to water quality in stream of Sekayu Recreational Forest, Terengganu. In Proccedings of the National Seminar in Science, Technology and Social Sciences (Vol. 1, pp. 279-286).

Yule, C. M. and Yong, H. S. (2004). Freshwater invertebrates of the Malaysian region. AkademiSains Malaysia.

Received: 03th August 2020; Accepted: $18^{\text {th }}$ September 2020; First distribution: $18^{\text {th }}$ October 2020. 